\title{
Methadone is safe for treating hospitalized patients with severe pain
}

\author{
[La méthadone est sans danger chez les patients hospitalisés qui éprouvent des \\ douleurs intenses]
}

Yoram Shir MD, Gila Rosen RN, Alexander Zeldin MD, Elyad M. Davidson MD

Purpose: Methadone is still regarded as a second line opioid for patients suffering from severe pain, and is rarely used in hospitalized patients. The infrequent use of methadone is probably due to its long plasma half-life that could lead to accumulation and toxicity. In the present study we report that clinically effective analgesic doses of methadone, given either epidurally or orally, can be used safely for prolonged treatment in hospitalized patients.

Clinical features: Over a five-year period we administered methadone at Hadassah Hospital in Jerusalem to 3,954 in-patients with severe pain, 12\% of whom were younger than $17 \mathrm{yr}$. Satisfactory pain relief was recorded in more than $85 \%$ of the patients. None of the patients treated with oral methadone developed serious side effects. Three patients, treated with epidural methadone $(0.09 \%)$, developed a clinically significant respiratory depression. In all three cases, epidural pump failure or pump misprogramming resulted in methadone overdose. None of the children or adults treated with methadone developed addiction during hospitalization.

Conclusion: Based on its analgesic properties and marked safety profile, we suggest that methadone could be added to the analgesic armamentarium of in-hospital health-care providers. Moreover, methadone could serve as the opioid of first choice in some inpatient populations.

Objectif : La méthadone est toujours considérée comme un opioïde mineur dans les cas de douleurs intenses. Elle est rarement prescrite aux patients hospitalisés. Cette situation est sans doute reliée à sa longue demi-vie plasmatique qui peut entraîner accumulation et toxicité. Nous montrons ici que des doses analgésiques efficaces de méthadone, administrées par voie épidurale ou orale, peuvent être utilisées sans danger comme traitement prolongé de patients hospitalisés.

Éléments cliniques : Pendant cinq ans, nous avons administré de la méthadone pour douleurs intenses à 3954 patients hospitalisés au
Hadassah Hospital de Jérusalem. Parmi eux, $12 \%$ avaient moins de 17 ans. L'analgésie a été satisfaisante chez plus de $85 \%$ des patients. Aucun effet secondaire important n'a été rapporté avec l'usage de la méthadone orale. Trois patients traités avec la méthadone épidurale $(0,09 \%)$ ont subi une dépression respiratoire significative. Une défaillance de la pompe épidurale ou une erreur de programmation avaient alors provoqué des surdoses de méthadone. Aucun enfant ou adulte traité avec la méthadone n'est devenu dépendant du médicament pendant l'hospitalisation.

Conclusion : Étant donné ses propriétés analgésiques et son remarquable profil d'innocuité, nous croyons que la méthadone pourrait s'ajouter à l'arsenal thérapeutique des patients hospitalisés. Elle peut aussi servir d'opiö̈de de premier choix chez certains patients hospitalisés.

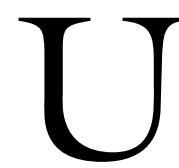

NDERTREATMENT of pain is common in hospitalized patients, children and adults. ${ }^{1}, 4 t$ is estimated that $50 \%$ of in-patients suffer substantial pain at some time. ${ }^{2}$ Although patients undergoing surgical procedures are more likely to suffer pain during hospitalization, more than $20 \%$ of non-surgical patients report substantial pain while in hospital. ${ }^{2,3}$

Opioids are the mainstay of therapy for pain due to malignancy and an important adjuvant in patients with pain of non-cancerous etiology. Nevertheless, almost $50 \%$ of in-patients that do receive opioids for their pain report moderate to severe pain. ${ }^{4}$

Methadone is a potent, highly lipid soluble and protein bound synthetic opioid, with a rapid onset of analgesia, large volume of distribution and prolonged half-life. ${ }^{5}$ While its analgesic effect during chronic treatment does not exceed $12 \mathrm{hr}$, its plasma half-life could be as long as $72 \mathrm{hr} .{ }^{6}$ Although favourable results

From the Pain Relief Unit, Department of Anesthesiology and Critical Care Medicine, Hadassah University Hospital, Jerusalem, Israel. Address correspondence to: Dr. Yoram Shir, Pain Relief Unit, Department of Anesthesiology, Hadassah University Hospital, Jerusalem 91120, Israel. Phone: +9722-6776911; Fax: +9722-6429392; E-mail: yshir@hadassah.org.il Accepted for publication July 5, 2001. Revision accepted August 29, 2001. 
were reported with methadone in the perioperative setting ${ }^{7-9}$ and in patients with chronic pain, ${ }^{10}$ its inhospital use is limited. This is probably due to several cases of serious side effects that were reported with methadone, when large doses were frequently administered, ${ }^{11-13}$ leading to gradual accumulation and toxic levels. ${ }^{14}$ At Hadassah Hospital in Jerusalem, however, methadone has been increasingly prescribed over the last two decades for patients with severe pain, mainly via the epidural and oral routes. We use epidural methadone to relieve postoperative $e^{15,16}$ or chronic pain conditions, ${ }^{17}$ whereas oral methadone is given for patients capable of oral intake, suffering persistent or chronic pain. ${ }^{18}$

More than 5,000 hospitalized patients received methadone at our hospital since 1995. The aim of this retrospective study was to examine its safety in a large patient population.

\section{Methods}

\section{Data collection}

Since January 1995, details of every patient treated by our in-hospital pain service were compiled in an electronic data base. These data include demographics, diagnosis, average daily pain scores, type and dose of analgesic drugs, other medical treatment, length of treatment and resulting complications including respiratory depression, sedation, itching, nausea and urinary retention. Patients' data were updated twice daily by the nursing and medical staff of the pain service and stored in the hospital's central database. For the purpose of the current survey, data of all hospitalized patients, labelled as treated with either "oral methadone" or "epidural methadone" between January 1995 and December 1999 were pooled. No hospitalized patient that received oral or epidural methadone during that time period was excluded from the study.

\section{Protocol of epidural methadone treatment}

Methadone $(0.1 \%$ in $10 \%$ glucose in children, or $0.2 \%$ in $10 \%$ glucose in adults) has been our opioid of choice for epidural analgesia in patients aged five years and older. Methadone was given epidurally to patients suffering from postoperative pain, pain following trauma, cancer pain, persistent or chronic low back pain and pain due to peripheral neuropathies and peripheral vascular disease. Following a methadone loading dose of $0.6 \mathrm{mg} \cdot 10 \mathrm{~kg}^{-1}$, a combination of bupivacaine, $0.125-0.25 \%$, with methadone, in an initial daily dose not exceeding $0.3 \mathrm{mg} \cdot \mathrm{kg}^{-1}$, was infused continuously, using battery operated infusion pumps (Graseby, Medical M26, U.K.) or PCA syringe pumps (P5000, IVAC, U.K.). Unless otherwise indicated (patients with moderate pain), the methadone dose was reduced to $0.2 \mathrm{mg} \cdot \mathrm{kg}^{-1} \cdot \mathrm{day}^{-1} 48 \mathrm{hr}$ after treatment began. Previous reports showed that plasma methadone levels in patients treated by epidural methadone in this dose range were within its analgesic range. ${ }^{16}$ Indications for terminating epidural methadone treatment included: (a) unrelieved severe or excruciating pain; (b) when epidural treatment was no longer indicated; (c) significant side effects, including urinary retention, itching, nausea and vomiting, mental clouding and respiratory depression; and $(\mathrm{d})$ infection at the site of epidural catheter insertion, with or without meningeal or systemic involvement. The duration of epidural methadone treatment was not an indication for its discontinuation.

\section{Protocol of oral methadone treatment}

Oral, racemic $0.1 \%$ methadone in glycerine was given to patients of all ages with severe persistent or chronic pain, capable of oral intake. Enrolled were patients fulfilling one of the following criteria: (a) pain that was not alleviated by non-opioid or other opioid medications; (b) significant side effects with other opioids; and (c) patients suffering from burn pain or pain due to peripheral vascular disease, where methadone served as the opioid of choice.

\section{ORAL METHADONE I N CHILDREN}

In infants and children younger than $10 \mathrm{yr}$, the initial daily dose of methadone did not exceed $0.2-0.4$ $\mathrm{mg} \cdot \mathrm{kg}^{-1} \cdot \mathrm{day}^{-1}$, bid-tid. When indicated, the methadone dose could be escalated daily, reaching a maximal allowed dose of $1 \mathrm{mg} \cdot \mathrm{kg}^{-1} \cdot \mathrm{day}^{-1} \cdot{ }^{18}$ Oral methadone was used routinely in children with cancer, after trauma and following burn injury.

\section{ORAL METHADONE I N ADULTS}

In opioid-naive adults, the initial methadone dose did not exceed 5-10 mg bid-tid, and was titrated carefully, according to the clinical response and side effects. These daily doses were reported previously to alleviate pain in chronic pain patients, with plasma levels well within methadone's analgesic range. ${ }^{5}$ Infrequently, larger initial methadone doses (up to $15 \mathrm{mg}$ tid) were prescribed for patients with intractable pain, not relieved by other opioid medications. The methadone dose was escalated in $20-30 \%$ increments according to clinical response and side effects, with no ceiling limitation. Oral methadone treatment was discontinued if pain persisted or when accompanied by significant side effects. 
TAB LE In-hospital pain treatment with methadone: age distribution, etiology and length of treatment

\begin{tabular}{|c|c|c|c|c|c|c|c|c|c|c|c|c|}
\hline \multirow{3}{*}{$\frac{\text { Age }}{\text { group }(y r)}$} & \multicolumn{5}{|c|}{ Epidural methadone } & \multicolumn{7}{|c|}{ Oral methadone } \\
\hline & \multicolumn{2}{|c|}{$\begin{array}{l}\text { Patients with } \\
\text { postoperative } \\
\text { pain }\end{array}$} & \multicolumn{2}{|c|}{$\begin{array}{l}\text { Patients with } \\
\text { non-surgical } \\
\text { pain }\end{array}$} & \multirow{2}{*}{$\begin{array}{l}\text { Length of } \\
\text { treatment } \\
\text { (days: median- } \\
\text { range) }\end{array}$} & \multicolumn{2}{|c|}{$\begin{array}{l}\text { Patients with } \\
\text { cancer pain }\end{array}$} & \multicolumn{2}{|c|}{$\begin{array}{l}\text { Patients with } \\
\text { burn pain }\end{array}$} & \multicolumn{2}{|c|}{$\begin{array}{l}\text { Patients with } \\
\text { other non- } \\
\text { malignant pain }\end{array}$} & \multirow{2}{*}{$\begin{array}{l}\text { Length of } \\
\quad \text { treatment } \\
\text { (days: median- } \\
\text { range) }\end{array}$} \\
\hline & male & female & male & female & & male & female & male & female & male & female & \\
\hline $1-9$ & 117 & 54 & 0 & 1 & $2(1-7)$ & 9 & 11 & 57 & 40 & 4 & 1 & $6(1-17)$ \\
\hline $10-17$ & 75 & 51 & 1 & 1 & $3(1-19)$ & 7 & 7 & 26 & 11 & 7 & 2 & $8(2-40)$ \\
\hline $18-29$ & 119 & 267 & 20 & 13 & $3(1-14)$ & 7 & 6 & 12 & 8 & 3 & 1 & $7(1-21)$ \\
\hline $30-39$ & 115 & 393 & 24 & 19 & $3(1-17)$ & 4 & 2 & 9 & 4 & 5 & 2 & $6(1-34)$ \\
\hline $40-49$ & 141 & 269 & 49 & 37 & $4(1-32)$ & 14 & 8 & 5 & 7 & 6 & 3 & 8 (3-97) \\
\hline $50-59$ & 185 & 223 & 49 & 40 & $3(1-7)$ & 19 & 25 & 3 & 3 & 19 & 17 & $8(3-23)$ \\
\hline $60-69$ & 327 & 246 & 29 & 36 & $3(1-9)$ & 24 & 16 & 3 & 1 & 14 & 13 & $7(1-34)$ \\
\hline Over 70 & 315 & 179 & 47 & 40 & $4(1-35)$ & 8 & 10 & 0 & 3 & 29 & 17 & $6(1-19)$ \\
\hline Total & \multicolumn{2}{|c|}{3036} & \multicolumn{2}{|c|}{406} & $3(1-35)$ & \multicolumn{2}{|c|}{177} & \multicolumn{2}{|c|}{192} & \multicolumn{2}{|c|}{143} & $7(1-97)$ \\
\hline
\end{tabular}

\section{Scoring scale}

Average daily pain scores were recorded using a verbal, five-point scale (none, mild, moderate, severe or excruciating). For sedation scoring we also used a fivepoint scale (patient fully alert - patient not arousable). Respiratory depression was defined as respiratory rate $<8 \cdot \mathrm{min}^{-1}$ in adults, $<12-16$ in children aged three to ten and $<20 \cdot \mathrm{min}^{-1}$ in children younger than two. Itching and nausea were recorded using a five-point verbal scale (none - intolerable).

\section{Monitoring}

Respiration, heart rate and sedation scores were monitored every four hours in children. Oxygen saturation was monitored continuously in children treated with epidural, but not oral methadone. Blood pressure, respiration, heart rate and sedation scores were monitored in adults every four to eight hours. Oxygen saturation was not monitored routinely in adults. Supplementary oxygen was not prescribed routinely, unless indicated for individual patients.

Results

From January 1995 to December 1999, 10,389 patients were treated by the in-hospital pain service. Of these, 3,954 patients (26\%) from 22 surgical and non-surgical wards were treated with methadone. Epidural methadone was used in 3,442 patients (87\%) while 512 patients were treated with oral methadone (Table). Twelve percent of patients treated with methadone were children younger than 17 , with a mean age of $4.1 \mathrm{yr}$. The youngest child receiving methadone was a ten-month-old female with burns covering $25 \%$ of her body surface area, who received oral methadone for eight days. Sixteen percent of the patients were older than 70 , treated for time periods as long as 35 days. The oldest was an 81 -yr-old male patient with lower limb ischemia treated with epidural methadone for 14 days.

\section{Epidural methadone}

Acceptable pain relief (none, mild or moderate pain scores) was reported by more than $90 \%$ of the patients. Three patients $(0.09 \%)$, receiving methadone for postoperative pain, developed a clinically significant respiratory depression, all within $36 \mathrm{hr}$ of surgery. These patients recovered completely once methadone was discontinued. In all three cases epidural pump failure or pump maladjustment resulted in methadone overdose. One of these patients, a 36-yr-old male patient after thoracic surgery, accidentally received $35 \mathrm{mg}$ of methadone via a high thoracic epidural catheter within $18 \mathrm{hr}$. This dose was due to a misprogramming of the pump. The other two patients received their daily dose of methadone over four to six hours due to electronic pump failure. Six chronic pain patients $(0.17 \%)$ developed clinically significant deep tissue or epidural infection. One of these patients required a surgical laminectomy for epidural abscess evacuation. No residual neurological deficit was recorded in any of these patients. Methadone treatment via the epidural route had to be discontinued in $7 \%$ of patients due to mental obtundation, itching, nausea or urinary retention.

\section{Oral methadone}

Acceptable pain relief was recorded for more than 85\% of the patients treated with oral methadone. The range of oral dose of methadone in children was 
0.1-1.1 mg $\cdot \mathrm{kg}^{-1} \cdot \mathrm{day}^{-1}$. However, only 12 children $(7 \%)$, suffering from cancer pain or pain after trauma, required daily methadone doses exceeding 0.6 $\mathrm{mg} \cdot \mathrm{kg}^{-1}$. The range of oral methadone in adults was 10-110 $\mathrm{mg} \cdot \mathrm{day}^{-1}$. However, only $12(6 \%)$ required daily methadone doses exceeding $60 \mathrm{mg}$. None of the children or adults treated with oral methadone developed respiratory depression or severe mental obtundation. Minor side effects (mental obtundation, itching, nausea and urinary retention), necessitating the substitution of oral methadone by another opioid, were recorded in $13 \%$ of the patients. No documented cases of addiction to methadone were recorded. Weaning from treatment with oral methadone was uneventful in all 182 methadone-treated children.

\section{Discussion}

To our knowledge, this clinical report is the first largescale survey examining the safety of methadone in hospitalized patients. We show that methadone, in doses previously reported to alleviate pain ${ }^{16,19,20}$ is safe in hospitalized patients suffering from acute or chronic pain. None of the patients treated with oral methadone, and only nine out of more than 3,400 patients treated with epidural methadone developed serious, life threatening side effects. Six patients in the epidural group developed infection, probably not related to methadone, whereas the other three developed respiratory depression, resulting from human error or pump failure. Thus, none of the patients receiving epidural methadone according to protocol developed respiratory depression.

Our results with epidural methadone are compatible with most previous studies where epidural methadone was used in pain patients. Not a single case of mortality or significant respiratory depression has been reported previously with epidural methadone after surgery or in chronic pain patients. This is probably due to methadone's lipophilicity that, in clinically relevant doses, induces its complete clearance from the cerebrospinal fluid before reaching the cisterna magna. ${ }^{21}$ Methadone possesses a dual analgesic effect when administered epidurally: a direct effect, through spinal mechanism, and a central effect, following its systemic accumulation. ${ }^{9,16}$ However, limiting the daily dose of epidural methadone to $0.3 \mathrm{mg} \cdot \mathrm{kg}^{-1}$ initially and decreasing the dose after $48 \mathrm{hr}$ prevent plasma accumulation. The three cases of respiratory depression reported here were all due to an accidental administration of methadone in doses significantly higher than planned.

Sporadic cases of methadone overdose, resulting in respiratory depression after oral administration, have been reported previously. Although daily fluctuations in blood concentrations in patients treated chronically with methadone are lower than with other opioids, ${ }^{22}$ its long plasma half-life may lead to intoxication. ${ }^{5}$ However, when adhering to the recommendations for chronic methadone treatment in adults, where initial doses of 5-10 mg are given every eight hours with gradual prolongation of this interval, ${ }^{19,20}$ the risk of overdose decreases significantly. In support of this conclusion, the present survey shows that the vast majority of patients treated according to these guidelines did not develop serious side effects.

More than 180 children were treated with oral methadone with no serious complications. Few reports have described the use of methadone in children. Most of these studies were conducted in the acute postoperative pain setting, ${ }^{8}$ while only three described the use of oral methadone in children with chronic pain. ${ }^{18,23,24}$ In contrast to adults, however, pharmacokinetic studies of methadone in children are not available. Thus, we chose to limit the daily dose of methadone in children to $1 \mathrm{mg} \cdot \mathrm{kg}^{-1}$. The lack of significant side effects in the present report indicates that, at this dose range, methadone is safe in hospitalized infants and children.

Albeit its long plasma half-life after repeated administration, methadone possesses other unique properties, making it suitable for treating patients with severe pain. It is inexpensive, well absorbed from the gastrointestinal tract (with up to $100 \%$ bioavailability), has a rapid onset of analgesic effect, appears to have no active metabolites and its clearance is probably not affected by hepatic or renal disease. ${ }^{5}$ Methadone has also antagonist activity at the $\mathrm{N}$-methyl-D-aspartate (NMDA) receptor. ${ }^{25}$ NMDA receptors are involved, among other functions, in neuropathic pain syndromes and in the development of opioid tolerance. Hence, methadone could be of special value in these patients.

We conclude that methadone, administered either epidurally or orally, is effective and safe for treating hospitalized children and adults suffering from acute or chronic pain. When administered according to strict guidelines, respiratory depression and other significant side effects were infrequent in nearly 4,000 patients. Several physicians hesitate to use methadone in hospitalized patients. Yet, when considering its safety profile, we suggest that methadone should be added to the analgesic armamentarium of in-hospital health-care providers.

\section{References}

1 Schechter NL. The undertreatment of pain in children: an overview. Pediatr Clin North Am 1989; 36: 781-94. 
2 Abbott FV, Gray-Donald K, Sewitch MJ, Johnston CC, Edgar L, Jeans ME. The prevalence of pain in hospitalized patients and resolution over six months. Pain 1992; 50: 15-28.

3 Donovan M, Dillon P, McGuire L. Incidence and characteristics of pain in a sample of medical-surgical inpatients. Pain 1987; 30: 69-78.

4 Owen H, McMillan V, Rogowski D. Postoperative pain therapy: a survey of patients' expectations and their experiences. Pain 1990; 41: 303-7.

5 Fainsinger R, Schoeller T, Bruera E. Methadone in the management of cancer pain: a review. Pain 1993; 52 : $137-47$.

6 Inturrisi CE, Colburn WA, Kaiko RF, Houde RW, Foley $K M$. Pharmacokinetics and pharmacodynamics of methadone in patients with chronic pain. Clin Pharmacol Ther 1987; 41: 392-401.

7 Gourlay GK, Willis RJ, Lamberty J. A double-blind comparison of the efficacy of methadone and morphine in postoperative pain control. Anesthesiology 1986; 64: 322-7.

8 Berde CB, Beyer JE, Bournaki MC, Levin CR, Sethna $N F$. Comparison of morphine and methadone for prevention of postoperative pain in 3-to-7 year-old children. J Pediatr 1991; 119(Pt 1): 136-41.

9 Wang JM, Knarr DC, Raj PP, Denson D. Continuous epidural methadone for the management of postoperative pain after lower abdominal surgery. Reg Anesth 1992; 17: 26-8.

10 Ripamonti C, Zecca E, Bruera E. An update on the clinical use of methadone for cancer pain. Pain 1997; 70: 109-15.

11 Ettinger DS, Vitale PJ, Trump DL. Important clinical pharmacologic considerations in the use of methadone in cancer patients. Cancer Treat Rep 1979; 63: 457-9.

12 Hunt G, Bruera E. Respiratory depression in a patient receiving oral methadone for cancer pain. J Pain Symptom Manage 1995; 10: 401-4.

13 Oneschuk D, Bruera E. Respiratory depression during methadone rotation in a patient with advanced cancer. J Palliat Care 2000; 16: 50-4.

14 Olsen Gd, Wendel HA, Livermore JD, Leger RM, Lynn

$R K$, Gerber N. Clinical effect and pharmacokinetics of racemic methadone and its optical isomers. Clin Pharmacol Ther 1977; 21: 147-57.

15 Evron S, Samueloff A, Simon A, Drenger B, Magora F. Urinary function during epidural analgesia with methadone and morphine in post-cesarean section patients. Pain 1985; 23: 135-44.

16 Shir $\Upsilon$, Eimerl D, Magora F, Damm D, SchulteMonting J, Chrubasik J. Plasma concentrations of methadone during postoperative patient-controlled extradural analgesia. Br J Anaesth 1990; 65: 204-9.
17 Shir Y, Yehuda Ben DB, Polliack A, Magora F. Prolonged continuous epidural methadone analgesia in the treatment of back and pelvic pain due to multiple myeloma. Pain Clin 1987; 1: 255-8.

18 Shir $\Upsilon$, Shenkman Z, Shavelson V, Davidson EM, Rosen $G$. Oral methadone for the treatment of severe pain in hospitalized children: a report of five cases. Clin J Pain 1998; 14: 350-3.

19 Sawe J, Hansen J, Ginman C, et al. Patient-controlled dose regimen of methadone for chronic cancer pain. BMJ 1981; 282: 771-3.

20 Paalzow L, Nilsson L, Stenberg P. Pharmacokinetic basis for optimal methadone treatment of pain in cancer patients. Acta Anaesthesiol Scand Suppl 1982; 74: 55-8.

21 Payne R, Inturrisi CE. CSF distribution of morphine, methadone and sucrose after intrathecal injection. Life Sci 1985; 37: 1137-44.

22 Gourlay GK, Cherry DA, Cousins MJ. A comparative study of the efficacy and pharmacokinetics of oral methadone and morphine in the treatment of severe pain in patients with cancer. Pain 1986; 25: 297-312.

23 Martinson IM, Nixon S, Geis D, YaDeau R, Nesbit M, Kersey J. Nursing care in childhood cancer: methadone. Am J Nurs 1982; 82: 432-5.

24 Miser AW, Miser JS. The use of oral methadone to control moderate and severe pain in children and young adults with malignancy. Clin J Pain 1986; 1: 243-8.

25 Gorman AL, Elliott KJ, Inturrisi CE. The d- and 1- isomers of methadone bind to the non-competitive site on the N-methyl-D-aspartate (NMDA) receptor in rat forebrain and spinal cord. Neurosci Lett 1997; 223: $5-8$. 